\title{
Relationship between duration of physical exercise and menstrual cycle female athletes in East Java Sports High School
}

\author{
Paula Eka Romadona \\ Department of Anthropology \\ Faculty of Social Science and Political Science, Universitas Airlangga, Surabaya \\ Address: Jalan Airlangga 4-6, Surabaya, Indonesia \\ E-mail: paula.eka.romadona-2016@fisip.unair.ac.id
}

\begin{abstract}
Exercise can be a supporting factor or inhibitor of reproductive health related to menstruation. East Java Sports High School is a particular school for athletes who have more intensive physical training than other public schools. This research was conducted to determine whether there is a significant relationship between the duration of physical exercise and the menstrual cycle in female athletes at East Java Sports High School. The method of this research is quantitative, with a sample of 60 respondents from 14 sports. Data is processed and calculated with Microsoft Excel and SPSS version 21, the statistical test used chi-square test. The calculation results obtained were $0.002<0.05$, so there is a significant relationship between the duration of physical exercise and the athlete's menstrual cycle at East Java Sports High School. That can be caused by excessive use of energy when practicing so that the energy in the body is out of balance which results in decreased pulsatile $\mathrm{GnRH}$, which can affect FSH. In addition, the results of calculations on the variable menstrual disorders in the form of physical disorders during menstruation obtained results $0.565>0.05$, so there is no significant relationship between the duration of physical exercise with menstrual disorders in athletes at East Java Sports High School.
\end{abstract}

Keywords: duration of physical exercise; menstrual cycle; menstrual disorders

Article History

Received: June 19, 2021

Accepted: October 27, 2021

Cite this as: Romadona PE (2021) Relationship between duration of physical exercise and menstrual cycle female athletes in East Java Sports High School. Indonesian Journal of Social Sciences 13 (2):95-100. DOI 10.20473/ijss.v13i2.27620.

\section{Introduction}

The role of women in sports is needed, especially in certain sports. With the increasing number of sports that require the participation of women, the number of female athletes continues to increase every year. Athletes are individuals who work as athletes or individuals who generally do sports (Saputri 2012). To filter and accommodate the interest of young athletes in Indonesia, the government carried out a program for the construction of special sports high schools.

The development of this sports school is accommodating the achievements of athletes both nationally and internationally. Moreover, this sports school pay attention to the academic and non-academic fields for athletes. It is intended that athletes can still practice sports according to their fields and continue their studies (Ariyanto 2015). In line with the profession, athletes have a responsibility to improve their ability and endurance through intensive training with short-term and long-term goals with a heavy level of competition (Mulyana 2010).

Strenuous and intensive exercise by athletes will have an impact on reproductive health. According to Wulandari \& Sa'adi (2013), the female reproductive system is sensitive to physiological pressures resulting from sports activities. So those women who have excessive sports activities tend to have 
menstrual disorders, amenorrhea and oligomenorrhea. Menstrual disorders are also influenced by the type and duration of exercise time.

The results of research from Yani (2016) showed that most of the athletes' physical activity was in the heavy category, from 39 people (88.6\%) who experienced oligomenorrhea as many as 26 people (27.3\%). The study results obtained a p-value $<0.05$, which means that there is a significant relationship between physical activity and the menstrual cycle in the athletes of the PON XIX contingent of West Java at KONI, South Sulawesi. Based on the facts, this research was conducted in a different place because East Java Sports High School is the only particular Sports High School in East Java with more intensive physical exercise time than other public schools. Based on the description in the introduction, the researcher wants to know: 1. is there a significant relationship between the duration of physical exercise and menstrual disorders in female athletes at East Java Sports High School? 2. Is there a significant relationship between the duration of physical exercise and the menstrual cycle in female athletes at East Java Sports High School?

\section{Methods}

The research method used is quantitative, using a non-parametric chi-square statistical test. The method was chosen to examine a particular population, data collection using research instruments, data analysis is quantitative or statistical (Sugiyono 2008). The sample of this research was taken by using the purposive sampling technique. This study provides inclusion criteria for prospective respondents, namely female athletes who are still active at East Java Sports High School, aged 15 to 18 years, have experienced menstruation. Giving age requirements to respondents is because generally, at the age of 15 years to 18 years, a person has attended high school level education and has experienced menstruation.

The sample used in this study was 60 respondents with 14 sports in Sports High School, namely Roller Skating, Swimming, Diving, Wrestling, Tennis, Athletics, Karate, Pencak Silat, Taekwondo, Judo, Rock Climbing, Beach Volleyball, Table Tennis, Sepak takraw. Data collection was done by using a questionnaire. The data obtained from the questionnaire was processed by coding data, namely changing the answers into number categories to make it easier to calculate using the help of Microsoft Excel and SPSS (Statistical Package for the Social Sciences) version 21.

\section{Results and Discussion}

This study was conducted at East Java Sports High School to determine whether or not there is a significant relationship between the duration of physical exercise with the menstrual cycle and menstrual disorders in athletes at East Java Sports High School.

The chi-square test was used to test whether or not there was a significant relationship between the duration of physical exercise and the menstrual cycle and menstrual disorders in athletes at East Java Sports High School.

Table 1 shows that the chi-square test can be seen that the significance p-value is 0.368 and the chisquare is 0.812 . Because the cross table is $2 \times 2$ and $50 \%$ cell is expected $(<5)$, we use the fisher exact test. At the fisher test is 0.565 (> 0.05), the null hypothesis $(\mathrm{H} 0)$ is accepted, which means that there is no significant relationship between the duration of physical exercise and menstrual disorders in female athletes at East Java Sports High School.

Menstrual disorders in the form of physical disorders experienced by respondents include feeling weak, nauseated, tired quickly, aches, back pain, breast pain, and pain in the lower abdomen, which are PMS symptoms (Premenstrual Syndrome). Menstrual disorders in the form of physical disorders 
experienced by respondents are not related to the duration of physical exercise and may be caused by hormonal factors in the body that trigger menstrual disorders.

Table 1.

Results of the chi-square test of physical exercise duration per day with menstrual disorders

\begin{tabular}{|c|c|c|c|c|c|}
\hline & & & \multicolumn{2}{|c|}{ Per Day } & \multirow{2}{*}{ Tota } \\
\hline & & & $<4$ hours & 4 hours & \\
\hline \multirow{2}{*}{\multicolumn{2}{|c|}{ Physical disorders }} & Yes & 34 & 23 & 57 \\
\hline & & No & 1 & 2 & 3 \\
\hline \multicolumn{3}{|c|}{ Total } & 35 & 25 & 60 \\
\hline \multicolumn{3}{|c|}{$\begin{array}{l}\text { Chi-Square } \\
\text { Chi-Square }\end{array}$} & \multicolumn{3}{|c|}{0.368} \\
\hline Value & \multicolumn{2}{|c|}{ Chi-Square } & \multicolumn{3}{|c|}{$0.812^{\mathrm{a}}$} \\
\hline Sig. & \multicolumn{2}{|c|}{ Fisher's Exact Test } & \multicolumn{3}{|c|}{0.565} \\
\hline $\begin{array}{l}\text { a. } \\
\text { b. }\end{array}$ & $\begin{array}{l}2 \text { cells }(50.0 \%) \text { hav } \\
\text { Computed only for }\end{array}$ & $\begin{array}{l}\text { cted cou } \\
\text { able. }\end{array}$ & & & \\
\hline
\end{tabular}

According to Sinaga et al. (2017), changes in the hormonal system that occur before menstruation are the leading cause of PMS, which occurs in someone with a sensitivity to changes in hormone levels that occur in the body before the arrival of menstruation. In addition, according to Ramadani (2013) the occurrence of PMS is caused by several factors, namely hormonal factors, chemical factors, genetic factors, psychological factors, physical activity factors, calcium, magnesium, vitamin b. Chemical factors are factors associated with symptoms of depression, anxiety, aggressiveness that affect the occurrence of PMS. Genetic factors are factors that are genetically inherited to cause PMS. Psychological factors that include stress also affect menstrual disorders. Physical activity factors such as the habit of not doing sports can trigger PMS. Consumption of sufficient calcium, magnesium, vitamin B will relieve PMS symptoms.

Table 2.

Chi-square test results of physical exercise duration per day with menstruation delay

\begin{tabular}{|c|c|c|c|c|c|}
\hline & \multicolumn{2}{|c|}{ Per Day } & \multirow[b]{2}{*}{ Total } \\
\hline & & & $<4$ hours & 4 hours & \\
\hline \multirow{2}{*}{\multicolumn{2}{|c|}{ Menstrual Delay }} & No & 23 & 19 & 42 \\
\hline & & Yes & 12 & 6 & 18 \\
\hline \multicolumn{3}{|c|}{ Total } & 35 & 25 & 60 \\
\hline \multirow{3}{*}{ Sig. } & \multirow{2}{*}{\multicolumn{2}{|c|}{$\begin{array}{c}\text { Chi-Square } \\
\text { Continuity Correction }\end{array}$}} & \multicolumn{3}{|c|}{0.391} \\
\hline & & & \multicolumn{3}{|c|}{0.568} \\
\hline & \multicolumn{2}{|c|}{ Chi-Square } & & $0.735^{\mathrm{a}}$ & \\
\hline Value & Continuit & Correction ${ }^{b}$ & \multicolumn{3}{|c|}{0.327} \\
\hline
\end{tabular}

a. 0 cells $(0.0 \%)$ have expected countless than 5 . The minium expected count is 7.50 .

b. Computed only for a $2 \times 2$ table

Source: Research data that has been tested using SPSS

Table 2 shows that the chi-square test can be seen that the significance p-value is 0.391 and the chisquare is 0.735 . Because the cross table is $2 \times 2$ and $0 \%$ cell is expected $(<5)$, we use the continuity correction value. At the continuity correction value of 0.327 and a significance p-value of 0.568 $(>0.05)$, the null hypothesis ( $\mathrm{H} 0)$ is accepted, which means that there is no significant relationship between the duration of physical exercise and menstrual delay in female athletes at East Java Sports High School. Based on these results, it was found that there was no significant relationship between the duration of physical exercise and the delay in menstruation experienced by the respondents. The 
number of respondents who never experienced a delay in menstruation is more than those who experienced a delay in menstruation. This is in line with research by Rich Edwards (2002) which states that in American women, increased physical activity is actually associated with a reduced risk of ovulation or menstrual problems. The addition of every hour of vigorous-intensity physical activity per week can reduce the risk of ovulation or menstrual problems by $7 \%$.

The occurrence of delays in menstruation experienced by respondents may be caused by hormonal factors in the body and can be caused by other factors. According to Kasdu (2005), the menstrual cycle factors include genetic factors, disease factors, dietary behaviour factors, and drug consumption. Of the factors mentioned, it will affect the hormonal system in the body so that it can affect the regularity of the menstrual cycle.

Table 3.

\begin{tabular}{|c|c|c|c|c|}
\hline & & Per & & Total \\
\hline & & $<4$ hours & 4 hours & Tolal \\
\hline & $<25$ days & 4 & 14 & 18 \\
\hline Menctrual Cyclo & $25-30$ days & 25 & 10 & 35 \\
\hline IVienstrual cycle & 31-36 days & 4 & 1 & 5 \\
\hline & $>36$ days & 2 & 0 & 2 \\
\hline Tot & & 35 & 25 & 60 \\
\hline Chi-Squ & e test & & 0,002 & \\
\hline Chi-Squa & value & & 14,521 & \\
\hline
\end{tabular}

Table 3 shows the value of the chi-square test can be seen that the significance p-value is 0.002 and the chi-square value is 14.521 . Because the table is $>2 \times 2$ and $0 \%$ cell expected $(<5)$, it uses a significant value from the Pearson chi-square test. In the Pearson chi-square test, the significance of the p-value is $0.002(<0.05)$, then the null hypothesis $(\mathrm{H} 0)$ is rejected, which means that there is a significant relationship between the duration of physical exercise and the menstrual cycle on female athletes at East Java Sports High School.

There are types of sports with a duration of physical exercise in this Sports High School <4 hours per day include Roller Skating, Athletics, Karate, Pencak Silat, Beach Volleyball, and Sepak Takraw. Moreover, sports with a physical exercise duration of 4 hours per day include Swimming, Diving, Wrestling, Field Tennis, Taekwondo, Judo, Rock Climbing, and Table Tennis.

The length of the cycle experienced by respondents is quite varied, the length of the menstrual cycle starting from $<25$ days per month, 25-30 days per month, 31-36 days per month, and $>36$ days per month. That can be interpreted as related to the disruption of the menstrual cycle pattern experienced by the respondent. According to Wei et al. (2009), menstrual cycles that occur <25 days in each month are short menstrual cycles, indicating the occurrence of polymenorrhea, while menstrual cycles that occur >36 days in each month are long menstrual cycles and indicate the occurrence of oligomenorrhea.

Research has also been conducted by Patras University Medical School, which states that disorders related to the menstrual cycle and delays in menarche experienced by young women occur due to intensive training lasting 15 hours or more in one week (Nattiv 2007). Menstrual cycle disorders that occur in this study include polymenorrhea and oligomenorrhea. Polymenorrhea and oligomenorrhea can cause the duration of physical exercise and exercise performed at least five times a week.

Polymenorrhea can be caused by anovulatory cycles often found in the sexual cycle when a person is in puberty. Anovulatory cycles occur because the increase in LH at preovulation is not significant 
enough. If ovulation cannot occur properly, the absence of ovulation will cause changes in the corpus luteum. So, it fails to thrive, resulting in no progesterone secretion during the latter part of the menstrual cycle and results in a shortening of the luteal phase so that the menstrual cycle shortens by several days (Tanudjaja et al. 2016).

The occurrence of oligomenorrhea is due to excessive energy. The energy in the body is not balanced, which results in a decrease in pulsatile $\mathrm{GnRH}$, which can affect $\mathrm{FSH}$, which results in a prolongation of the follicular phase (Tanudjaja et al. 2016). That shows that the longer the duration of physical exercise, the more likely it is to have menstrual cycle disorders.

That is in line with research conducted by Asmarani \& Hardian (2010), which says that the type of exercise, intensity, duration of exercise, and the rate of development of training programs can affect the severity of menstrual cycle disorders. According to Anderson (1994) in Irianto (1997), a good portion of the exercise to improve and maintain body fitness is carried out for 20-60 minutes without stopping. Physical exercise with high intensity and not balanced with adequate energy intake can cause endocrine disorders in the body, resulting in one of the causes of menstrual cycle irregularities (Jorge EC et al. 2008 in Yani 2016). Special Sports Schools adapted the physical demands placed on young women to their physiological conditions, ensuring that exercise does not adversely influence menstruation. The duration of the cycle has the only minor effect. The "negative" effect - no significant link - is a good sign in this study because it demonstrates proper pupil health care.

\section{Conclusion}

The research concludes that there is no significant relationship between the duration of physical exercise and menstrual disorders in female athletes at East Java Sports High School. Furthermore, the analysis results regarding the relationship between the duration of physical exercise and the delay in menstruation showed no significant relationship between the duration of physical exercise and the delay in menstruation in female athletes at East Java Sports High School.

Furthermore, there is a significant relationship between the duration of physical exercise and the menstrual cycle in female athletes at East Java Sports High School. The results of the analysis showed the presence of polymenorrhea and oligomenorrhea in the respondents. That proves that the duration of physical exercise that is too long can inhibit the regularity of the menstrual cycle. This research needs to be developed further related to the same theme. It is recommended in further research to focus on the length of study, and it is necessary to increase the number of samples so that the data obtained is varied. Furthermore, the research relies on questionnaires, therefore subjective reporting of menstrual features may influence the self-reported answer. As a result, it is possible that females reported what they think is expected of them rather than what is actually going on in their bodies.

\section{Acknowledgements}

This research would not be possible without the support of various parties. First, Dr. Lucy Dyah Hendrawati, S.Sos., M.Kes., as the supervisor of this research. Second, all research respondents are at East Java Sports High School. Thank you for the suggestions and constructive criticism during the writing of this research.

\section{References}

Ariyanto W (2015) Survei Management Sekolah Menengah Atas Negeri Olahraga (SMANOR) Kabupaten Sidoarjo Tahun 2015. Skripsi, Universitas Negeri Semarang, Semarang. 
Asmarani R \& Hardian (2010) Pengaruh olahraga terhadap siklus haid atlit. [Diakses 22 Oktober 2021] pp. 2-20. http://scholar.googleusercontent.com/scholar?q=cache:BpWr-S7oZtgJ:scholar.go ogle.com/+Asmarani+R+(2010)+Pengaruh+Olahraga+Terhadap+Siklus+Haid.+Artikel+Penelitia $\mathrm{n}: 1 \% \mathrm{E} 2 \% 80 \% 9320 . \& \mathrm{hl}=$ en\&as_sdt=0,5\&as_vis=1.

Irianto PD (1997) Olahraga yang aman dan efektif untuk kebugaran. Cakrawala Pendidikan 1:115127.

Kasdu D (2005) Solusi Problem Wanita Dewasa. Jakarta: Puspa Swara, Anggota IKAPI.

Mulyana BR (2010) Keterlambatan menarche dan gangguan menstruasi akibat dari latihan olahraga yang berat pada atlet renang. Jurnal Kepelatihan Olahraga 2 (1):10-20.

Nattiv AL, Loucks AB, Manore MM, Sanborn CF, Borgen JS, \& Warren MP (2007) American College of Sport Medicine position stand. The Female Athlete Triad. Med. Sci Sport Exercise 39 (10): $1867-1882$.

Ramadani M (2013) Premenstrual syndrome (PMS). Jurnal Kesehatan Masyarakat 7 (1):21-25.

Rich-Edwards JW, Spiegelman D, Garland M, Hertzmark E, Hunter DJ, Colditz GA, Willett WC, Wand H, \& Manson JE (2002) Physical activity, body mass index, and ovulatory disorder infertility. Epidemiology 13 (2):184-90.

Saputri GARR \& Dieny FF (2012) Female athlete triad pada atlet putri di Pusat Pendidikan Latihan (Pusdiklat) Ragunan Jakarta. Journal of Nutrition College 1 (1):405-413.

Sinaga E, Saribanon N, Suprihatin, Sa'adah N, Salamah U, Murti YA, Trisnamiati A, \& Lorita S (2017) Manajemen Kesehatan Menstruasi. In: Manajemen Kesehatan Menstruasi. Universitas Nasional, IWWASH, Global One.

Sugiyono PD (2008) Metode Penelitian Kuantitatif Kualitatif dan R\&D.

Tanudjaja ML, Polii H, \& Wungouw SIH (2016) Gambaran menstruasi atlit basket di SMAN 9 Manado. Jurnal e-Biomedik 4 (1):39-42.

Wei S, Schmidt MD, Dwyer T, Norman RJ, \& Venn AJ (2009) Obesity and menstrual irregularity: associations with SHBG, testosterone, and insulin. Obesity 17 (5):1070-1076.

Wulandari DA \& Sa'adi A (2013) The effect of physical exercise and diet with oligomenorrhea in female athletes. $1-11$.

Yani NG (2016) Hubungan Aktivitas Fisik Dengan Siklus Menstruasi Pada Atlet Kontingen PON XIX Jawa Barat di KONI Sulawesi Selatan. Skripsi, Universitas Hasanuddin. 